$\operatorname{cocos}(2004), 16,43-55$

Printed in Sri Lanka

\title{
EFFECTIVENESS OF USED ENGINE OIL IN THE MANAGEMENT OF COCONUT MITE, ACERIA GUERRERONIS (ACARI: ERIOPHYIDAE)
}

\author{
K A S Chandrasiri and L C P Fernando \\ Coconut Research Institute, Lunuwila, Sri Lanka
}

\begin{abstract}
The effectiveness of applying used engine oil on nuts in the management of coconut mite, Aceria guerreronis Keifer (Acari: Eriophyidae) was determined. The numbers of coconut mites were significantly lower on nuts treated with $20 \%, 30 \%$ and $40 \%$ concentrations of used engine oil than that of untreated nuts, at Udappuwa. The nuts treated with $30 \%$ mixture of used engine oil were free from coconut mites until 60 days and negligible thereafter indicating that it is the best concentration. Similar results were obtained when the method was repeated at Anuradhapura. The predatory mite, Neoseiulus aff. paspalivorus was drastically affected by the treatment. A study conducted in three infested plantations at Udubaddawa, Mampury and Anuradhapura indicated that the incidence of damage in treated palms were significantly lower than in control palms. There were less than $3 \%$ nuts with fresh damage in treated palms compared to over $50 \%$ damaged nuts in control palms in all three locations. Similarly, percentage of nuts with discontinued damage was considerably higher in treated palms than in control palms. The percentage of nuts with no damage at harvest was significantly higher in treated palms than in untreated palms irrespective of location, pick and frequency of application. The percentage of damaged nuts in the untreated newly developed bunches of treated palms were significantly lower than that of untreated palms and this percentage declined with time in all locations. The results indicate that the application of used engine oil at monthly intervals is the best frequency of application that resulted in the highest percentage of nuts with no damage and the lowest damage incidence on newly developed nuts as recorded at Udubaddawa. Application of $30 \%$ used engine oil at 2-montly intervals is recommended for the management of coconut mite. The advantages and disadvantages of this method are discussed.
\end{abstract}

\section{INTRODUCTION}

The coconut mite, Aceria guerreronis (Acari: Eriophyidae) has proven to be one of the most serious and intractable pests of coconut in the world. So far, no effective and sustainable method has been developed to manage 
the pest successfully. Several attempts are being made to develop biological control methods using the predatory mite Neoseiulus aff. paspalivorus in Sri Lanka (Fernando and Aratchige, 2003) and the entomopathogenic fungus Hirsutella thompsonii in India (Rabindra and Kumar, 2003), Cuba (Lampedro and Rosas, 1989; Cabrera, 1995) and Sri Lanka. Currently the only effective method to suppress the pest is the use of pesticides. In the past, many highly toxic pesticides such as monocrotophos, chinomethionate and cyhexatin (Mariau and Tchibozo; 1973; Mariau, 1977; Julia and Mariau, 1979) have been used to suppress the pest. Although these pesticides give effective control of coconut mite their action is not long lasting. Therefore, repeated applications at short intervals are required to maintain the pest numbers at low levels. Moreover, high toxicity, harmful effects on the environment and natural enemies, difficulties in application and uneconomical nature have made these pesticides unacceptable as a long-term measure. Since the report of the coconut mite in India (Sathiamma et al., 1998) and Sri Lanka (Fernando, 1998) in late 1998 attention was drawn on using low toxic chemicals. In India various formulations of neem (azadirachtin) such as $2 \%$ neem and garlic mixture, arishtu, nimbicidine, neemazal TS, econeem and neemazin have been advocated (Nair, 2002; Madhavan Nair et al., 2002; Rethinam, 2003; Rethinam et al., 2003). In Sri Lanka spraying of neem oil and garlic mixture, NeemAzal $1 \%$ and bagging young bunches with sulphur have been found effective (Fernando et al., 2002; Wickramanada et al., 2003) and have been recommended. Neem oil mixture and NeemAzal reduced the pest population by only about $60 \%$ (Fernando et al., 2002). Therefore, it is necessary to repeat applications at $11 / 2-2$ months intervals to maintain the pest population at a low level. Bagging with sulphur reduced the pest population by about $95 \%$ but the main disadvantages of this method were premature shedding of nuts during dry periods and necessity to climb the tree twice for a single application, which is costly. Therefore, identification of low toxic chemicals that that would give nearly complete kill of the pest is important to successfully reduce the pest damage in a short period.

The study was aimed at determining the effectiveness of applying used (waste) engine oil, which is low cost and readily available in the management of the coconut mite.

\section{MATERIALS AND METHODS}

\section{Determination of a suitable concentration}

The effect of three concentrations of used (waste) engine oil; $20 \%, 30 \%$ and $40 \%$ were evaluated in a coconut mite infested estate at Udappuwa (Puttalum District). Ten infested palms were selected for each treatment including the control. The different concentrations were prepared by adding 
$80 \mathrm{ml}, 70 \mathrm{ml}$ and $60 \mathrm{ml}$ of water to $20 \mathrm{ml}, 30 \mathrm{ml}$ and $40 \mathrm{ml}$ of used engine oil respectively. A small amount of detergent and about one teaspoon of wheat flour was added to the mixture and stirred well to prevent separation of oil and water. The mixture was applied lightly on the perianth and the nut surface around the perianth of all nuts (infested and un-infested) in 2 - 6 month old bunches. The second bunch from the fully opened inflorescence was considered as the 2-month old bunch. A single 2-5 month old nut was picked from each of the treated and control palms at 5, 15, 30, 45, 60 and 90 days after treatment and the number of live coconut mites and predatory mites (Neoseiulus aff. paspalivorus) were recorded.

The same procedure was repeated in a coconut mite infested estate at Anuradhapura using 30\% concentration of used engine oil. Bunches of twenty palms were treated as described. Ten palms were used as the control. A single nut from each of 2-5 month old bunches was selected at $15,30,45,75$ and 90 days after treatment and the number of coconut mites on each nut were recorded.

\section{Determination of effect of application}

A pilot trial was conducted to determine the effect of applying $30 \%$ mixture of used engine oil on the incidence of damage following treatment and at harvest, advancement of damage to newly developing bunches and the frequency of application. The trial was conducted in coconut mite infested plantations at Udappuwa (Kurunegala District), Mampury (Puttalum District) and Anuradhapura. One-acre block was selected from each plantation. In each palm 2-5 month old bunches were treated with $30 \%$ mixture of used engine oil as described previously. The treatments were repeated at 1,2 and 3-monthly intervals at Udappuwa, Mampury and Anuradhapura respectively. At the subsequent round of treatment, all previously untreated bunches up to 2-month old bunches were applied with used oil.

In each plantation 20 treated palms in the one-acre block and 20 untreated palms adjoining the treated block were marked. In each of the 20 selected palms, 2- and 4-month old bunches were marked before the first round of treatment and the total number of nuts in each bunch was recorded. In the untreated palms, 2 and 4 month old bunches were similarly marked and total number of nuts were recorded. Prior to the second round of treatment, the total number of nuts and the number of damaged nuts (fresh and discontinued) in the previously marked bunches were recorded. At the second round of treatment the 2- and 4-month old bunches present at the time of application were marked and the data recorded as for the first round. In Udubaddawa where the treatments were repeated monthly, the 2and 3-month old bunches were marked because 4-month old bunch had been already treated at the previous occasion. During the first 3 rounds of treatments in all three plantations the total number of nuts and damaged 
nuts in the two untreated bunches immediately before the youngest treated bunch were recorded. When the treated bunches were harvested, the nuts in the marked palms were collected separately and were categorized in to 5 groups $(A-E)$ according to the degree of damage. They were undamaged and normal sized nuts (category A), damaged and normal sized nuts (category B), damaged and smaller sized nuts (category C) and undamaged and smaller sized nuts (category E). Data for two picks wère recorded. The data for harvested nuts were not recorded at Mampury.

\section{RESULTS}

\section{Determination of a suitable concentration}

The data on the counts of live coconut mites were analysed using Maximum Likelihood Chi-square test. The mean number of live coconut mites on the treated nuts were significantly lower $(P<0.0001)$ than that of untreated nuts at Udappuwa. The mite numbers were negligible on all treated nuts from 15 days of treatment until the end of sampling (Table 1). Of the three concentrations used, the nuts treated with $30 \%$ used engine oil was free from live mites from 15 to 60 days indicating that it is the most suitable concentration for treatment. It is important to note that the predatory mite populations in the treated nuts were drastically affected by the treatment (Table 2).

Table 1: Mean number of live coconut mites recorded on nuts treated with three concentrations of used engine oil and on untreated nuts at different intervals after treatment at Udappuwa

\begin{tabular}{lrrrrrrr}
\hline Treatment & \multicolumn{7}{c}{ Sampling day } \\
\cline { 2 - 7 } & 5 & 15 & 30 & 45 & 60 & 90 \\
\hline $20 \%$ oil & 2.0 & 0 & $0.6(1)$ & 0 & 0 & $0.4(1)$ \\
$30 \%$ oil & 11.2 & 0 & 0 & 0 & 0 & $0.7(1)$ \\
$40 \%$ oil & 4.2 & $0.1(1)$ & $0.7(1)$ & 0 & 0 & $1.1(1)$ \\
\hline Control & $346.3(10)$ & $719.6(10)$ & $282.1(10)$ & $534.5(10)$ & $537.2(10)$ & $494.5(10)$ \\
\hline
\end{tabular}

- The numbers in the parentheses are the numbers of nuts coconut mites were present.

Table 2: Total number of predatory mites recorded from nuts treated with different concentrations of used engine oil at Udappuwa

\begin{tabular}{llllll}
\hline Treatment & \multicolumn{5}{c}{ Sampling day } \\
\cline { 2 - 6 } & 15 & 30 & 45 & 60 & 90 \\
\hline $20 \%$ oil & 0 & 0 & 0 & $8(1)$ & 0 \\
$30 \%$ oil & 0 & $7(1)$ & $2(1)$ & $5(2)$ & 0 \\
$40 \%$ oil & 0 & 0 & $2(1)$ & $6(2)$ & 0 \\
\hline Control & $15(3)$ & $27(5)$ & $57(8)$ & $24(7)$ & $8(3)$ \\
\hline
\end{tabular}

- $\quad$ The numbers in the parentheses are the numbers of nuts on which predatory mites were present. 
In Anuradhapura too the number of live coconut mites on treated nuts were significantly lower $(P<0.0001)$ than the number on untreated nuts confirming the results of the previous experiment. The mean numbers of coconut mites on the treated nuts were $0.1,0.3,0.1$ and 0.8 at $15,30,45$, 75 and 90 days respectively. In the untreated nuts of the control palms the mean numbers of coconut mites were 520.1, 845.0, 753.7 and 725.7 on the same respective days.

\section{Determination of the effect of application}

\section{Damage incidence following treatment}

The data on the incidence of damage in engine oil treated and untreated palms were analysed using Maximum Likelihood Analysis of Variance. The comparisons of percentage in nuts with fresh damage, discontinued damage and no damage were analysed separately for each round of observations at each location. In all the cases there was a significant difference $(P<0.0001)$ between the treated and untreated palms. There were less than $3 \%$ nuts with fresh damage on treated palms compared to over $50 \%$ in control palms after 2 rounds of treatment in all three locations (Figure 1). The fresh damage that was present at the time of treatment was discontinued after the treatment. The percentage of nuts with discontinued damage was considerably higher in treated palms than in control palms (Figure 1). The percentage of undamaged nuts in the treated palms was much higher than that in untreated palms (Figure 1). The results indicated that treatment with used engine oil significantly reduces the incidence of damage in coconut. After the first round of treatment the percentage of nuts with no damage was almost the same in all three plantations. But, after second round the highest percentage of undamaged nuts was recorded from Udubaddawa followed by Mampury and Anuradhapura (Figure 1) suggesting that application at monthly intervals would give the lowest damage incidence. 


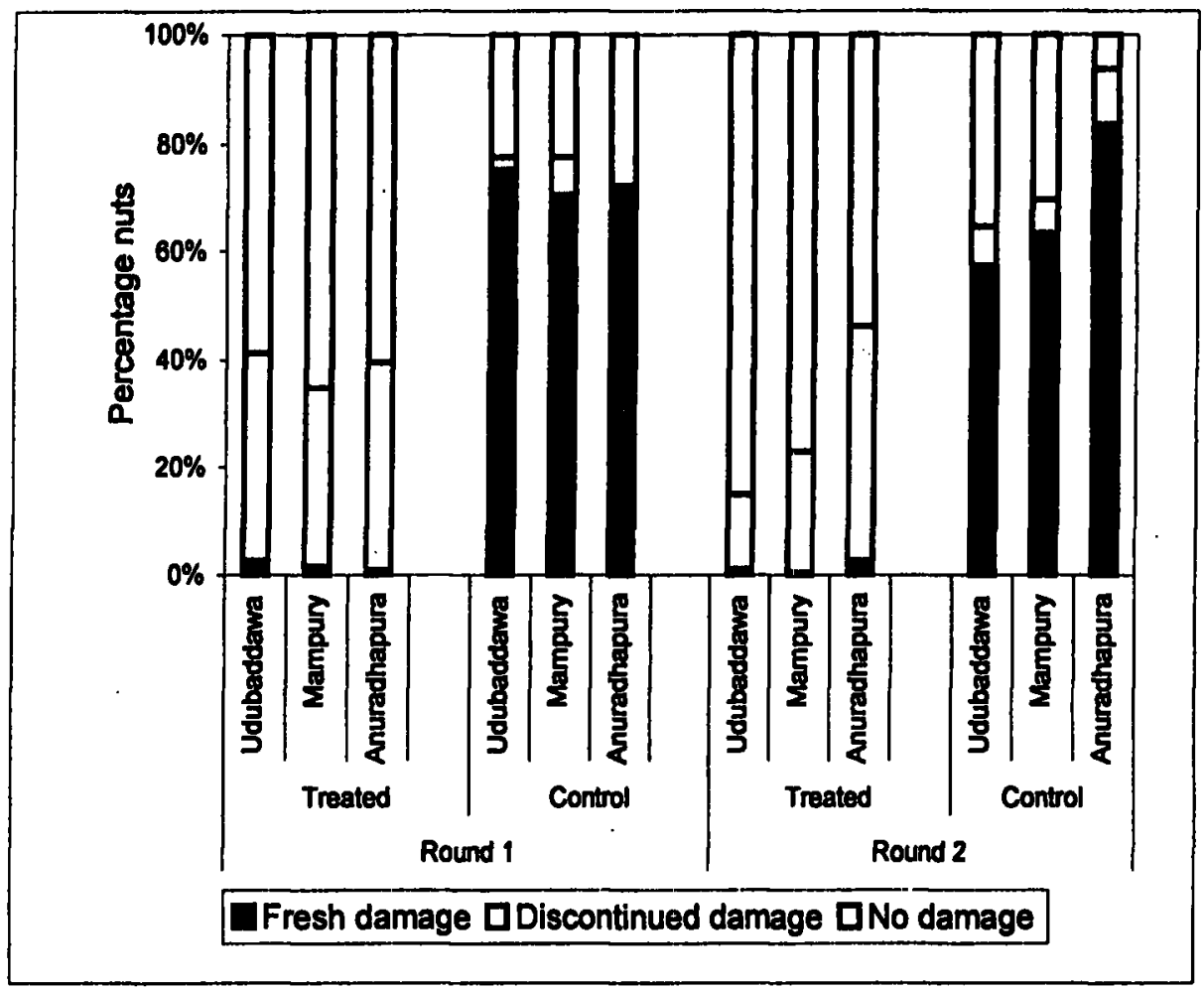

Figure 1: Percentage of nuts with fresh damage, discontinued damage and without damage in treated and untreated palms after two rounds of treatments at Udubaddawa, Mampury and Anuradhapura

\section{Damage incidence in newly doveloped bunches}

The percentage nut damage in the two newly developed bunches above the youngest treated bunch were compared with that of untreated palms using $Z$ statistics. The number of damaged nuts in the two bunches were pooled and analysed separately for each round of treatment and location. The percentage of damaged nuts in the newly developed untreated bunches in treated palms were significantly lower than that in untreated palms, in almost all cases. The percentage of damaged nuts in the newly developed bunches was lowest at Kuliyapitiya followed by Mampury and Anuradhapura (Figure 2).

Also, the percentage of damage in untreated palms was low at Udubaddawa and Mampury compared to Anuradhapura. The application of used engine oil at monthly interval gave the lowest damage incidence in newly developed bunches. In all the three plantations there was a decreasing trend in the percentage of damage in treated palms with time (Figure 2). The rate of decrease in percentage damage at Udubaddawa, 
Mampury an Anuradhapura were similar at 2, 4 and 6 months following application (Figure 3).

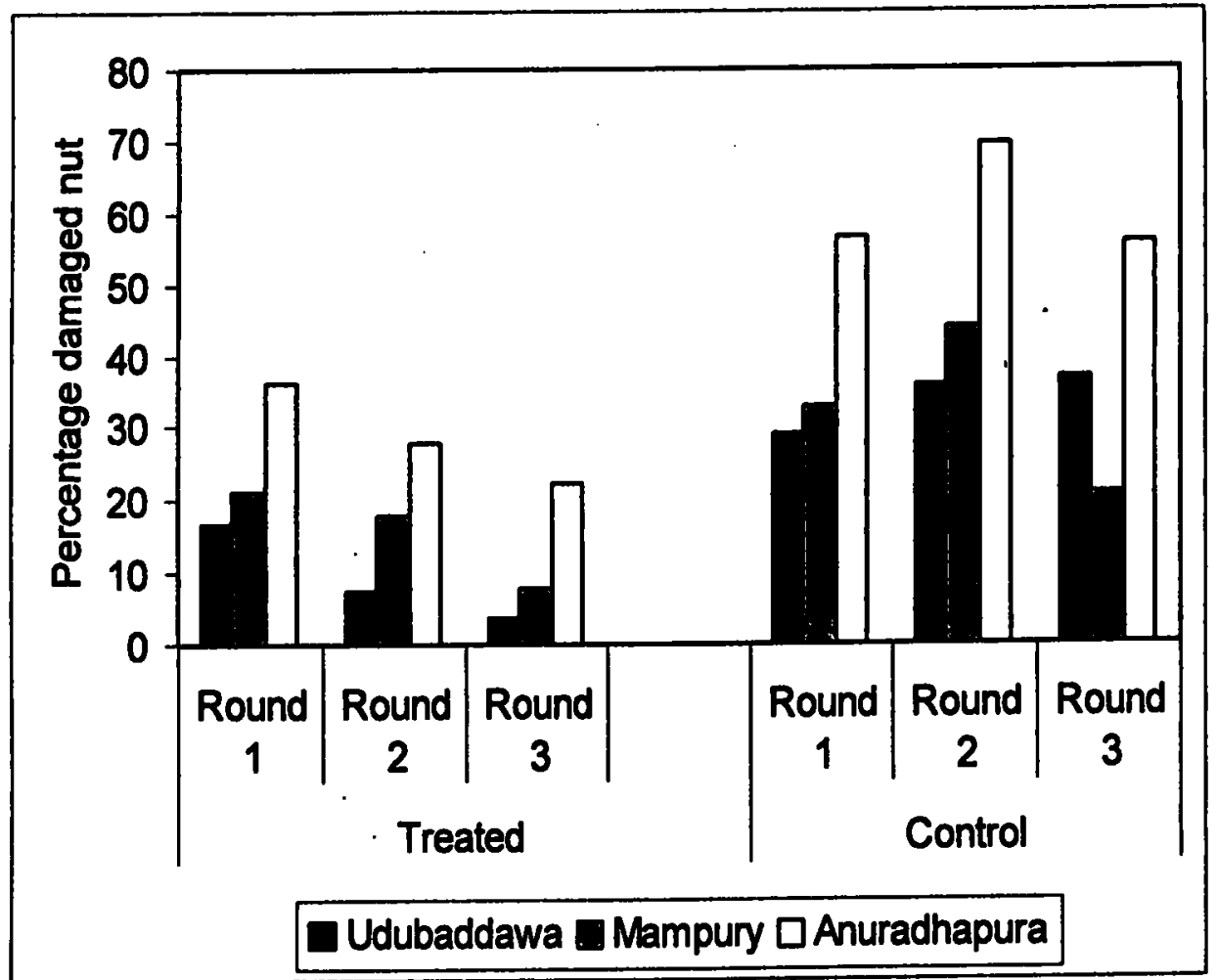

Figure 2: Percentage of damaged nuts in newly developed bunches of treated and untreated palms in three rounds of treatments at Udubaddawa, Mampury and Anuradhapura 


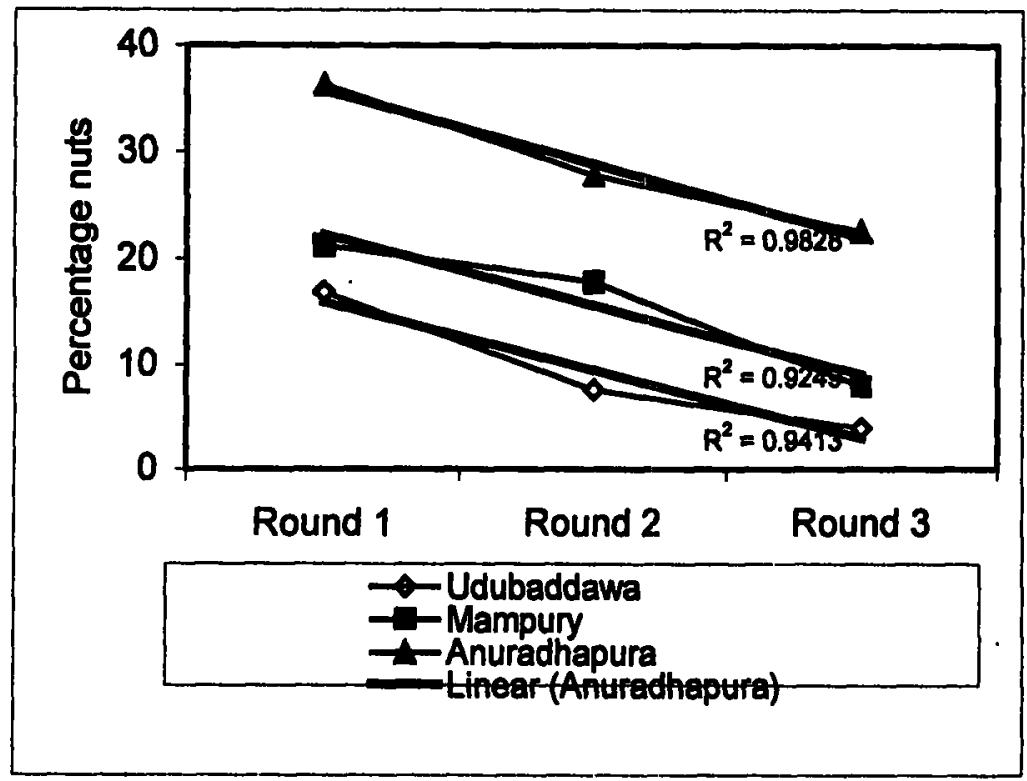

Figure 3: The rate of decrease in percentage of damage at Udubaddawa, Mampury and Anuradhapura, 2, 4 and 6 months after first application

\section{Damage incidence in harvested nuts}

Z-statistics was used to compare the proportion of nuts in each category (A-E) at each pick and location separately. In both treated and untreated palms over $90 \%$ of nuts were in categories A and B. However, the percentage of nuts with no damage (category $A$ ) was significantly higher in treated palms than that of untreated palms irrespective of location (frequency of application) and pick (Table 3). The percentage of nuts with no damage was higher at Udubaddawa than at Anuradhapura indicating that monthly application is effective than three-monthly application. Also, the percentage of damaged smaller sized nuts and damaged deformed nuts were lower in treated palms than in untreated palms (Table 3). 
Table 3: Percentage of undamaged and normal sized nuts (category $A$ ), damaged and normal sized nuts (category B), damaged and smaller sized nuts (category $C$ ) and undamaged and smaller sized nuts (category E) in selected palms and results of comparisons between treated and untreated palms in two picks at Udubaddawa and Anuradhapura

\begin{tabular}{|c|c|c|c|c|c|c|c|c|c|c|}
\hline \multirow{2}{*}{$\begin{array}{l}\text { Location, } \\
\text { treatment and } \\
\text { category }\end{array}$} & \multicolumn{5}{|c|}{ Pick 1} & \multicolumn{5}{|c|}{ Pick 2} \\
\hline & $\bar{A}$ & $B$ & C & $D$ & $\bar{E}$ & $\bar{A}$ & B & C & $\bar{D}$ & $\bar{E}$ \\
\hline Udubaddawa & & & & & & & & & & \\
\hline $\begin{array}{l}\text { Treated } \\
\text { Control } \\
\text { Significance } \\
\text { Anuradhapura }\end{array}$ & $\begin{array}{l}32.7 \\
17.7\end{array}$ & $\begin{array}{l}64.2 \\
74.6\end{array}$ & $\begin{array}{l}1.7 \\
6.1\end{array}$ & $\begin{array}{l}0.4 \\
1.6 \\
\text { N.S. }\end{array}$ & $\begin{array}{l}0.8 \\
0.0 \\
\text { N.S. }\end{array}$ & $\begin{array}{l}89.2 \\
15.0 \\
\star\end{array}$ & $\begin{array}{l}1.0 \\
79.7 \\
\end{array}$ & $\begin{array}{l}0.5 \\
2.7 \\
\text { N.S. }\end{array}$ & $\begin{array}{l}0.0 \\
2.7 \\
\text { N.S. }\end{array}$ & $\begin{array}{l}0.0 \\
0.0 \\
-\end{array}$ \\
\hline $\begin{array}{l}\text { Treated } \\
\text { Control } \\
\text { Significance }\end{array}$ & $\begin{array}{l}59.0 \\
17.3 \\
\star\end{array}$ & $\begin{array}{l}38.5 \\
73.0\end{array}$ & $\begin{array}{l}1.7 \\
8.2 \\
+\end{array}$ & $\begin{array}{l}0.0 \\
1.0 \\
\text { N.S. }\end{array}$ & $\begin{array}{l}0.8 \\
0.5 \\
\text { N.S. }\end{array}$ & $\begin{array}{l}57.0 \\
14.8\end{array}$ & $\begin{array}{l}36.6 \\
75.2 \\
\end{array}$ & $\begin{array}{l}2.5 \\
6.7\end{array}$ & $\begin{array}{l}1.6 \\
3.4 \\
\text { N.S. }\end{array}$ & $\begin{array}{l}2.7 \\
0.0 \\
\text { N.S. }\end{array}$ \\
\hline
\end{tabular}

\section{Effect on nut fall}

The number of nuts fallen from each marked bunch in each round of treatment was determined by calculating the difference in the number of nuts in the bunch before treatment and prior to subsequent round of treatment. Number of fallen nuts in the marked bunches in the untreated palms were also determined, similarly. The data for the two bunches were pooled and the percentages were calculated considering the total number of nuts in each bunch prior treatment. No adverse effects of application of used engine oil on nut fall were recorded. The percentage of nut fall in treated and untreated bunches were not different in the first two rounds of treatment at all three sites (Table 4).

Table 4: Percentage of nut fall in 2- and 4-month old nuts in treated and untreated palms in two rounds of treatment at Udubaddawa, Mampury and Anuradhapura

\begin{tabular}{lrr}
\hline Location and treatment & Round 1 & Round 2 \\
\hline Udubaddawa & 12.9 & 23.7 \\
Treated & 15.4 & 19.7 \\
Control & & \\
Mampury & 18.7 & 28.6 \\
Treated & 29.0 & 28.0 \\
Control & & $\cdot$ \\
Anuradhapura & 25.0 & 19.8 \\
Treated & 41.6 & 18.6 \\
Control & \\
\hline
\end{tabular}




\section{DISCUSSION}

Application of used engine oil on bunches of coconut mite infested palms was highly effective in reducing nut damage to a very low level. Engine oil application resulted in nearly complete mortality of coconut mites on infested nuts and the treated nuts remained free of re-infestation until the end of sampling, which was 3 months after application (Table 1). The application resulted in discontinuation of damage and very low percentage of fresh damage on treated bunches (Figure 1). More importantly the treatment resulted in a large proportion of nuts without damage compared to the palms in untreated control (Figure 1 and Table 3). The incidence of damage on untreated developing bunches in treated palms was significantly lower than that of untreated palms and gradually reduced over time (Figure 2). The results suggest that damage to nuts could be maintained at low levels by repeated application of newly developing untreated nuts at monthly or bi-monthly intervals.

The treatment did not cause additional nut fall, except the nut fall due to physiological reasons (Table 4). However, an important drawback in the use of engine oil is that it killed the predatory mites on the treated nuts (Table 2).

Application of used engine oil on nuts has both curative and preventive action. The results and observations clearly indicated that a single application of an infested nut is sufficient to prevent re-infestation until the nut is harvested. Similarly treatment of un-infested nuts prevented infestation until harvest. However, the effectiveness of engine oil depends on the proper preparation of the mixture and application. Because the mixture of engine oil and water tends to separate to two layers it is necessary to thoroughly mix them just before application. Also, it is necessary to apply the mixture manually by hand to ensure that the surface is well covered as required. It is important that the mixture is applied around the perianth and on the area of the nut surface below the perianth. If any area on the perianth is missed coconut mites under such areas may not be killed or migrating mites could enter through such gaps resulting in reinfestation. When the mixture is applied to the perianth and the nut surface it seep in and spreads underneath the bracts killing the mites therein. Also, the mixture sticks to the bracts and the nut surface for a long period preventing re-infestation until the nuts are harvested. Nuts applied with the mixture have a blackish appearance, which fades away with time, sometimes leaving a dark green patch. Depending on the source of used engine oil and the time of application (dry season) shallow, brown longitudinal fissures may appear on the nut surface, which does not harm the nuts. 
Although the treated nuts remain free of mites until harvest and the developing young bunches show lesser incidence of damage the untreated nuts should be treated should be repeatedly to maintain the damage at a very low level. It was seen that application at short intervals is the best but for practical reasons bi-monthly applications are suggested.

There are several practical difficulties associated with the application. It is necessary to climb each tree and apply the mixture on to 3-6 month old bunches at first application and the newly developed bunches in the subsequent applications. Due to the shortage of experienced climbers, cost of labour and time taken for application (about 30 trees/ day/ climber) this method cannot not be conveniently used in large plantations. However, in large plantations heavily infested blocks or selected palms could be treated by this method. For home gardens and small-holdings this is the best method known so far to reduce damage considerably. It is strongly recommended to use this method in newly infested areas and in boundary areas of infestation to obtain near complete control of the pest.

The method is not only effective but cost effective compared to the commercially available pesticides. It is readily available locally areas and could be applied even during rainy weather. Moreover, it is non-toxic to the consumers of coconuts and is safe to the handlers and the environment. The analysis of nut water and kernel of treated and untreated nuts showed that these did not contain heavy metals above the tolerable limits. In both treated and untreated nuts trace amounts of some heavy metals were found in similar quantities indicating that harmful substances present in used engine oil has not been absorbed by the edible parts of the coconut.

The only foreseeable harmful side effect of the application of used engine oil is its effect on predatory mites. The treatment causes mortality of predatory mites in treated nuts. This in a way provides a better opportunity to the unaffected predatory mites to handle the low pest population on untreated nuts more effectively. Therefore, the application of used engine oil could be an important component in the integrated management of the coconut mite to reduce its population to a very low level. If it is followed by augmentation of predatory mite and/ or application of Hirsutella fungus the pest can be maintained at economically non-damaging levels in the longterm. Work is being continued to further confirm the frequency of application and to develop a mixture that could be applied as a spray. 


\section{ACKNOWLEDGEMENTS}

We thank staff of the Crop Protection Division for their assistance in carrying out the field trials and the owners of the coconut estates for permitting us to conduct the studies in their estates. We are grateful to Dr. T.S.G. Peiris for analysing the data. Financial assistance was provided by the coconut CESS fund.

\section{REFERENCES}

Cabrera, R.I.C. (1995). Un 'medio a base de soya mas azucar para la var. thompsonii en medio liqido. 111 Encuentro Nac. Cient-Tec. De Bioplaguicidas. Expo-CREE. La Habana, Cuba. pp. 11-12.

Fernando, L.C.P. (1998). Report of the Crop Protection Division. Annual Report of the Coconut Research Institute of Sri Lanka. pp. 135-156.

Fernando, L.C.P. Wickramanada, I.R. and Aratchige, N.S. (2002). Status of coconut mite, Aceria guerreronis in Sri Lanka. In Proceedings of the International workshop on coconut mite (Aceria guerreronis) 2000. Eds. Fernando, L.C.P., Moraes, G.J. de and Wickramananda, I.R., Coconut Research Institute, Sri Lanka, January 6-8. pp. 1-8.

Fernando, L.C.P. and Aratchige, N.S. (2003). Use of predatory mite Neoseiulus aff. paspalivorus in management of coconut mite (Aceria guerreronis). In Coconut eriophyid mite - Issues and strategies. Eds. H. P. Singh and P. Rethinam. pp. 43-49. Proceedings of the International workshop on coconut mite. Bangalore, India, 2003.

Julia, J.F. and Mariau, D. (1979). Nouvelles recherches en Cote-d'Ivoire sur Eriophyes guerreronis $\mathrm{K}$., acraien ravageur des noix du cocotier. Oléagineux. 34, 181-189.

Lampedro, L. and Luis Rosas, J. (1989). Selection of Hirsutella thompsonii Fisher strains to fight coconut mite Eriophyes guerreronis Keifer. 1. Pathogenecity experiments. Revista Mexicana de Micologia. 5, 225231.

Madhavan Nair, G. Mathew, T.B. Saradamma, K. and Beevi, N. (2002). Infestation of coconut mite (Aceria guerreronis K.) in the southern Indian State, Kerala. In Proceedings of the International workshop on coconut mite (Aceria guerreronis) 2000. Eds. Fernando, L.C.P., Moraes, G.J. de and Wickramananda, I.R., Coconut Research Institute, Sri Lanka, January 6-8. pp. 32-40. 
Mariau, D. (1977). Aceria (Eriophyes) guerreronis : an important pest of african and american coconut groves. Oléagineux. 32, 101-108.

Mariau, D. and Tchibozo, H.M. (1973). Essais de lutte chimique contre Aceria guerreronis (Keifer) Oléagineux. 28, 133-135.

Nair, C.P.R. (2002). Status of coconut eriophyid mite Aceria guerreronis Keifer in India. In Proceedings of the International workshop on coconut mite (Aceria guerreronis) 2000. Eds. Fernando, L.C.P., Moraes, G.J. de and Wickramananda, I.R., Coconut Research Institute, Sri Lanka, January 6-8. pp. 9-12.

Rabindra, R.J. and Sreerama Kumar, P. (2003). Prospects of biological control of coconut mite. In Coconut eriophyid mite - issues and strategies. Eds. H. P. Singh, and P. Rethinam. pp 35-42. Proceedings of the International workshop on coconut mite, Bangalore, India, 2003.

Rethinam, P. Singh, S.P. Hallikeri, V. and Gopalakrishnan, R. (2003). Eriophyid mite in coconut. Coconut Development Board, Kochi, India p. 32.

Rethinam, P. (2003). International efforts on coconut eriophyid mite (Aceria guerreronis Keifer) problem - an overview. In Coconut Eriophyid mite: Issues and strategies. Proceedings of the International workshop on coconut mite, Bangalore, India, 2003. Eds. Singh, H.P. and Rethinam, P. Coconut Development Board, Kochi, India. pp. 10-21.

Sathiamma, B. Radhakrishnan Nair, C.P. and Koshy, P.K. (1988). Outbreak of a nut infesting eriophyid mite Eriophyes guerreronis (K.) in coconut plantations in India. Indian Coconut Journal. 29(2), 1-3.

Wickramananda, I.R. Fernando, L.C.P. and Aratchige, N.S. (2003). Use of chemicals for management of coconut mite: Sri Lanka Experience. In Coconut eriophyid mite - Issues and strategies. Eds. H.P. Singh and $P$. Rethinam. Proceedings of the International workshop on coconut mite held in Bangalore, India. 5-7 April 2003. pp. 50-56. 